5. Quirk, R., Greenbaum, S., Leech, G., \& Svartvik, J. (1985). A comprehensive grammar of the English language. London: Longman. from http://bookre.org/reader?fi le $=777220$

DOI https://doi.org/10.30525/978-9934-26-073-5-1-54

ЕМОТИВНІСТЬ ХУДОЖНЬОГО ТЕКСТУ: Е. СIГАЛ «LOVE STORY»

\author{
Закреницька Л. А. \\ кандидат філологічних наук, дочент, \\ дочент кафедри іноземних мов \\ Хмельницької гуманітарно-педагогічної академії
}

Воротняк Л. І.

кандидат педагогічних наук, дочент, дочент кафедри іноземних мов

Хмельницької гуманітарно-педагогічної академіі

м. Хмельницький, Украйна

Мова, як основний інструмент людського спілкування, не тільки забезпечує інформаційний обмін мовців, але й відображає їх емоційний стан в акті комунікації. Емоційні стани характеризуються взаємозв'язком із психічними процесами і властивостями особистості, що зумовлює необхідність їх різнобічного вивчення. Актуальність дослідження різних аспектів емотивності в лінгвістиці визначається важливістю вивчення проблеми вербального прояву людських почуттів, переживань та емоцій.

Першим, хто зробив спроби конкретизувати поняття емотивності, був Ш. Баллі. Він розмежував поняття емоційність і емотивність, надаючи лінгвістичного статусу лише останньому, та вважав емотивність характеристикою тексту/лексикону, що відображає в мові/мовленні мисленнєву емоційну діяльність людини [1].

Емотивна лексика (далі - ЕЛ) $є$ важливим чинником у вираженні емоцій в мовленні, та разом з низкою одиниць інших мовних рівнів вона створює емотивний фон художніх творів. Емотивність лексичних одиниць розглядають як їх здатність закріплювати у своїй семантиці вказівку на емоційне ставлення до об'єкта номінації, а при аналізі тексту враховують те емоційне співпереживання, яке він викликає у читача. На думку В.I. Шаховського, емотивна лексика виявляє очевидну, всім 206 
відому і сталу емотивність, іiі адекватно розуміють комуніканти i в контексті, і поза ним [6, с. 200]. На наявність у значенні емотивної лексики семи емотивності указують також Н.I. Бойко, О.О. Селіванова, I.В. Чепуріна [2, с. 15; 4, с. 142; 5, с. 84] та інші дослідники.

Емотивність художнього тексту забезпечують одиниці різних мовних рівнів: фонетичний, морфологічний, лексичний та синтаксичний. Емотивними засобами (далі - Е3) на фонетичному рівні $є$ інтонація, темп, тембр тощо. Емоції на морфологічному рівні виражаються в словах, емоційне ставлення яких до предмета зумовлене особливими афіксами. Емоційні конотації на лексичному рівні створюються в мові завдяки емотивно-оцінним прикметникам, прислівникам, іменникам та дієсловам, які містять оцінку у своїй структурі. Синтаксичний рівень характеризується широким спектром засобів передачі емоцій: повтори, інверсія, емфатичне використання дієслова $d o$, короткі, відривчасті конструкції, що слідують одна за одною. На фоно-графічному рівні засобами вираження емоцій є знаки оклику та питання, курсив, великі літери, три крапки, тире й дефіс та інші.

В межах невербальних засобів комунікації виокремлюють кінетичні (жести, міміка, мова рухів тіла), просодичні (тембр, інтонація, паузи) та проксемні (простір, дистанція, територія тощо). У художньому творі автор часто використовує невербальні засоби через опис рухів, міміки та жестів героїв $з$ метою максимального забезпечення розуміння стану, емоцій та настрою героїв читачем. Емотивний текст презентує емоційну інформацію за допомогою як мінімум одного емотивного засобу лінгвістичного чи паралінгвістичного, який виражає емоцію, усвідомлювану усіма учасниками акту комунікації.

В структурі емотивності тексту розмежовують план змісту і план вираження. Емотивність змісту тексту полягає, з одного боку, у наявності емотем у когнітивному змісті тексту, а 3 іншого, - у наявності емотивного компонента у прагматичних стратегіях автора. Емотивність художнього тексту виражається через особливості його текстової семантики, природу людських емоцій, які відображають внутрішній стан суб'єкта та результат його взаємодії із світом [3, 109]. Зокрема, в своєму романі «Love Story» Ерік Сігал змальовує одвічну проблему кохання, зокрема кохання двох молодих людей - Олівера Барретта та Дженніфер Кавіллері, які є виходцями з різних соціальних та культурних прошарків суспільства. Проте їхнє кохання проходить через усі соціальні, етнічні та релігійні бар'єри. Олівер готовий втратити всі привілеї спадкоємця з тим, щоб бути з Дженніфер. 
Емотивність роману Е. Сігала «Love Story» актуалізується значною сукупністю мовних та текстових маркерів емоцій. В аналізованому творі простежуємо значну кількість емотивних лексичних одиниць різних частин мови, зокрема прикметники (fierce, grim, admirable) - 40\% усієї ЕЛ, дієслова (bellow, detest, delight) - 37\% усієї ЕЛ, іменники (fury, endearment) - 16\% усієї ЕЛ та прислівники (ominously) - 7\% усієї ЕЛ. Емотивна лексика в романі є переважно корінними словами (irk, sob) $60 \%$ усієї ЕЛ), домінантними є також суфіксальні лексичні утворення (distressing, loving) - $29 \%$ усієї ЕЛ, найменш репрезентативними емотивними лексемами є складні слова (crestfallen) - 3\% усієї ЕЛ. Переважна більшість емотивної лексики виявляє інгерентну емотивність (agitate, gloat) - 92\% усієї ЕЛ, проте подекуди трапляються приклади адгерентної емотивності, де слова реалізують значення емотивності в межах контексту (to thunder, to bulldoze (me)) - 7\% усієї ЕЛ.

Вербальними засобами вираження емоційних станів в романі $\epsilon$ фразеологічні звороти tear your hair (out), be taken aback, make somebody sick, not to give someone the time of the day та інші.

Емотивний ефект роману простежується також через використання не літературної, грубої лексики, на кшталт «sonovabitch», для характеристики Олівером свого батька.

Засоби вираження емотивності спроможні позначати цілий спектр почуттів та емоцій людини. В творі Е. Сігала «Love Story» негативна емотивність (60\% усіх ЕЗ) переважає над позитивною (40\% усіх ЕЗ). Позитивна емотивність представлена такими семантичними групами, як радість, любов, захоплення, щастя, здивування, задоволення, спокій, а негативна емотивність - як страх, роздратування та гнів, збентеження, ненависть, презирство/відраза, страждання/горе, розчарування, відчай, смуток та сором. Домінантними семантичними групами $\epsilon$ такі, що позначають емоції гніву/роздратування (15\% усіх Е3) та страху (14\% усіх Е3), «любов» (10 \% усіх Е3) та «задоволення» (9\% усіх Е3). Негативна емотивність зумовлена, на нашу думку, сюжетом твору. Негативні емоції персонажів виявляються у ході розгортання багатьох подій: стосунки Олівера з батьком, його дитячі спогади, поразка у хокейному матчі, труднощі перших років спільного життя з Дженні, хвороба і смерть коханої тощо.

Усі використані автором роману мовні засоби створюють відповідний емотивний фон та емотивну тональність тексту, що сукупно забезпечує відповідний прагматичний вплив на читача. 


\title{
Література:
}

1. Балли Ш. Общая лингвистика и вопросы французского языка. Москва, 2001. 416 с.

2. Бойко Н. I. Українська експресивна лексика: семантичний, лексикографічний і функціональний аспекти: Монографія. Ніжин: Видво „Аспект-Поліграф», 2005. 552 с.

3. Графова Т. А., Шахнарович А. М. Экспериментальное исследование реализации эмотивности в речевой деятельности. Человеческий фактор в языке : Языковые механизмы экспрессивности. Москва : Наука, 1991. С. 99-114.

4. Селіванова О. О. Основи теорії мовної комунікації: Підручник. Черкаси: Видавництво Чабаненко Ю.А., 2011. 350 с.

5. Чепурина И. В. Семантическая структура эмотивных производных (на примере отглагольных имён существительных со значением лица). Учёные записки Таврического наи. ун-та им. В. И. Вернадского. 2001. Т. 14 (53). № 1. С. 84-91 (Серия «Филология»).

6. Шаховский В. И. Категоризация эмоций в лексико-семантической системе (на материале английского языка): дис. ... доктора филол. наук : 10.02.04. Москва, 1988. 402 с.

DOI https://doi.org/10.30525/978-9934-26-073-5-1-55

\section{ВТОРИННІ НОМІНАЦІЇ НЕВИЗНАЧЕНОЇ КІЛЬКОСТІ МЕТОНІМІЧНОЇ ПРИРОДИ: ЛІНГВІСТИЧНИЙ АСПЕКТ}

\author{
Зінченко А. В. \\ викладач кафедри германської філології \\ Сумського державного університету \\ м. Суми, Украӥна
}

Кількість як універсальна категорія обов'язково знаходить своє мовне вираження як у первинних, так і вторинних номінаціях. За неможливості виразити точно надто великі чи малі кількісні характеристики об'єкту реальності, людина вдається до опосередкованих назв, так званих вторинних номінацій кількості.

Вторинна номінація невизначеної кількості - це номінація, утворена внаслідок метафоричного чи метонімічного перенесення, яка експлікує невизначено велику чи невизначено малу кількісну ознаку об'єкта. Відмітно, що метонімічний механізму перенесення постійно перебуває у 